Article

\title{
A New Tetrahydrofuran Lignan Diglycoside from Viola tianshanica Maxim
}

\section{Yan Qin ${ }^{1}$, Chengle Yin ${ }^{1}$ and Zhihong Cheng ${ }^{1,2, *}$}

1 Department of Pharmacognosy, School of Pharmacy, Fudan University, Shanghai 201203, China

2 Key Laboratory of Modern Chinese Preparation, Jiangxi University of Traditional Chinese Medicine, Ministry of Education of China, Nanchang 330004, China

* Author to whom correspondence should be addressed; E-Mail: chengzhh@fudan.edu.cn; Tel.: +86-21-5198-0157.

Received: 11 September 2013; in revised form: 10 October 2013 / Accepted: 18 October 2013 / Published: 4 November 2013

\begin{abstract}
A new lignan glycoside, tianshanoside A (1), together with a known phenylpropanoid glycoside, syringin (2) and two known lignan glycosides, picraquassioside C (3), and aketrilignoside B (4), were isolated from the whole plant of Viola tianshanica Maxim. The structure of the new compound was elucidated by extensive NMR $\left({ }^{1} \mathrm{H},{ }^{13} \mathrm{C}, \mathrm{COSY}, \mathrm{HSQC}\right.$, HMBC and ROESY) and high resolution mass spectrometry analysis. The three lignans $\mathbf{1}, \mathbf{3}$, and $\mathbf{4}$ did not exhibit significant cytotoxicity against human gastric cancer Ags cells or HepG2 liver cancer cells. This is the first report of the isolation of a lignan skeleton from the genus Viola L.
\end{abstract}

Keywords: Viola tianshanica; lignan; tianshanoside A; cytotoxicity

\section{Introduction}

Viola tianshanica Maxim (Violaceae) is a perennial herb widely distributed in Central Asia, especially in the Xinjiang Uygur Autonomous Region (XUAR) of China [1]. The whole herb, including the roots, have been used in traditional Uygur medicines as an antifebrile and detoxicating agent for the treatment of fever, headache, pharyngalgia and acute pyogenic infections such as boils, furuncles and carbuncles [2]. Modern pharmacological studies have demonstrated that the extracts of $V$. tianshanica have anti-inflammatory [3], anti-bacterial [4] and anti-oxidative [5] activities. It is used in XUAR as a substitute for Viola yedoensis. Very little is known about the phytochemical composition of $V$. tianshanica 
with the exception of several flavonol-O-glycosides [6] and cyclotides [7] that have been reported. As part of our continued investigation of the constituents of $V$. yedoensis and its substitutes [8,9], a phytochemical study of the ethanolic extract of the herb was thus carried out. Herein, we report the isolation and structural elucidation of a new lignan glycoside, tianshanoside A (1), along with three known glycosidic lignan derivatives, syringin (2) [10], picraquassioside C (3) [11], and aketrilignoside B (4) [12] (Figure 1), from V. tianshanica. Compounds 1, 3, and 4 were evaluated for their cytotoxicity against the human gastric cancer (Ags) and liver cancer HepG2 cell lines.

Figure 1. Structures of compounds 1-4.
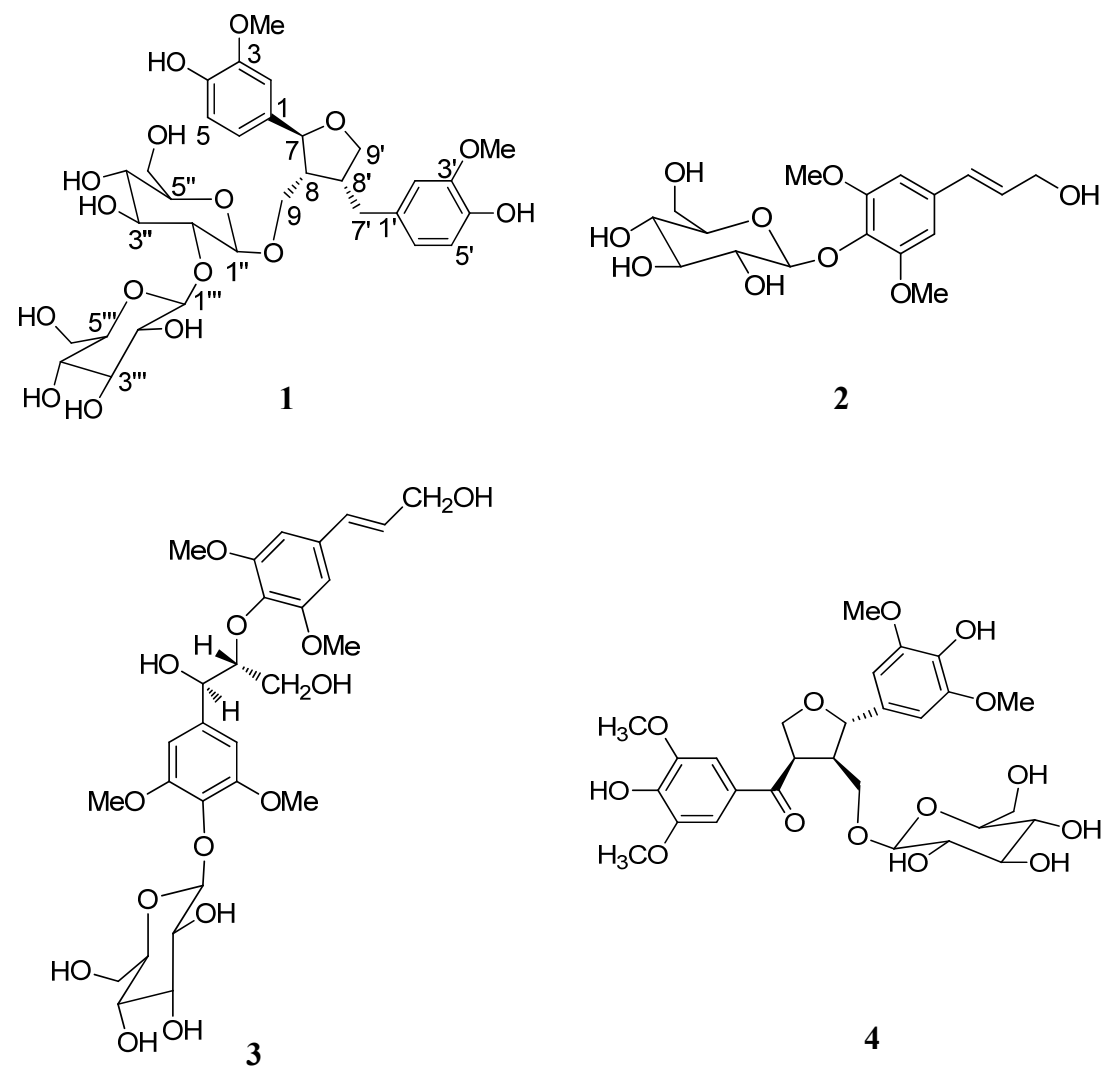

\section{Results and Discussion}

Repeated column chromatography of the ethyl acetate fraction of the ethanolic extract of $V$. tianshanica led to the isolation of a new tetrahydrofuran lignan diglycoside (1). Compound $\mathbf{1}$ was obtained as a white amorphous powder and possessed the molecular formula of $\mathrm{C}_{32} \mathrm{H}_{44} \mathrm{O}_{16}$ as evidenced by a HRESIMS peak at $m / z 707.2531[\mathrm{M}+\mathrm{Na}]^{+}$in combination with its ${ }^{1} \mathrm{H}-\mathrm{NMR},{ }^{13} \mathrm{C}-\mathrm{NMR}$ and DEPT spectra. Maximum absorption bands at 230 and $280 \mathrm{~nm}$ in the UV spectrum suggested the existence of conjugated groups in $\mathbf{1}$. The IR spectrum exhibited absorption bands for free hydroxyl groups $\left(3387 \mathrm{~cm}^{-1}\right)$ and benzene rings (1637 and $1513 \mathrm{~cm}^{-1}$ ). Detailed analysis of ${ }^{1} \mathrm{H}-\mathrm{NMR}$ (Table 1) and HSQC spectra showed that 1 contained two ABX spin systems assignable to two 1,3,4-trisubstituted benzene rings at $\delta_{\mathrm{H}}$ $6.64(1 \mathrm{H}, d, J=8.0 \mathrm{~Hz}, \mathrm{H}-5), 6.68(1 \mathrm{H}$, brs, H-6), and $6.82(1 \mathrm{H}, \mathrm{brs}, \mathrm{H}-2)$; and 6.69 (1H, brs, H-5'), 6.62 $\left(1 \mathrm{H}, \mathrm{dd}, J=8.0,1.4 \mathrm{~Hz}, \mathrm{H}-6^{\prime}\right)$, and $6.73\left(1 \mathrm{H}, \mathrm{d}, J=1.4 \mathrm{~Hz}, \mathrm{H}-2^{\prime}\right)$. 
Table 1. ${ }^{1} \mathrm{H}-(600 \mathrm{MHz})$ and ${ }^{13} \mathrm{C}-\mathrm{NMR}(150 \mathrm{MHz})$ data of compound $\mathbf{1}$ (in $\mathrm{CD}_{3} \mathrm{OD}, \delta$ in ppm, $J$ in $\mathrm{Hz}$ ).

\begin{tabular}{cccccc}
\hline No. & $\boldsymbol{\delta}_{\mathbf{H}}$ & $\boldsymbol{\delta} \mathbf{c}$ & No. & $\boldsymbol{\delta}_{\mathbf{H}}$ & $\boldsymbol{\delta} \mathbf{c}$ \\
\hline 1 & - & 134.4 & $8^{\prime}$ & $2.62 \mathrm{~m}$ & 42.1 \\
2 & $6.82 \mathrm{brs}$ & 110.1 & $9^{\prime}$ & $3.54 \mathrm{dd}(7.6,7.6), 3.82 \mathrm{dd}(7.5,7.5)$ & 72.3 \\
3 & - & 147.7 & $\mathrm{C}-3-\mathrm{OMe}$ & $3.72 \mathrm{~s}$ & 55.6 \\
4 & - & 145.5 & $\mathrm{C}-3^{\prime}-\mathrm{OMe}$ & $3.72 \mathrm{~s}$ & 55.6 \\
5 & $6.64 \mathrm{~d}(8.0)$ & 115.3 & Glc-1" & $4.32 \mathrm{~d} \mathrm{(7.7)}$ & 101.4 \\
6 & $6.68 \mathrm{brs}$ & 118.7 & $2^{\prime \prime}$ & $3.30 \mathrm{~m}$ & 81.9 \\
7 & $4.76 \mathrm{~d}(6.4)$ & 81.7 & $3^{\prime \prime}$ & $3.13 \mathrm{~m}$ & 76.2 \\
8 & $2.31 \mathrm{~m}$ & 50.1 & $4^{\prime \prime}$ & $3.13 \mathrm{~m}$ & 69.7 \\
9 & $3.64 \mathrm{~m}, 3.88 \mathrm{dd}(9.5,6.4)$ & 66.7 & $5^{\prime \prime}$ & $3.41 \mathrm{~m}$ & 76.3 \\
$1^{\prime}$ & - & 131.8 & $6^{\prime \prime}$ & $3.44 \mathrm{~m}, 3.66 \mathrm{~m}$ & 60.8 \\
$2^{\prime}$ & $6.73 \mathrm{~d}(1.4)$ & 112.9 & Glc-1'"' & $4.43 \mathrm{~d}(7.8)$ & 104.4 \\
$3^{\prime}$ & - & 147.3 & $2^{\prime \prime \prime}$ & $2.99 \mathrm{~m}$ & 74.7 \\
$4^{\prime}$ & - & 144.5 & $3^{\prime \prime \prime}$ & $3.13 \mathrm{~m}$ & 76.7 \\
$5^{\prime}$ & $6.69 \mathrm{brs}$ & 115.0 & $4^{\prime \prime \prime}$ & $3.03 \mathrm{~m}$ & 69.9 \\
$6^{\prime}$ & $6.62 \mathrm{dd}(8.0,1.4)$ & 120.8 & $5^{\prime \prime \prime}$ & $3.03 \mathrm{~m}$ & 77.0 \\
$7^{\prime}$ & $2.82 \mathrm{dd}(13.5,4.3)$, & 32.4 & $6^{\prime \prime \prime}$ & $3.99 \mathrm{dd}(9.5,6.4), 3.58 \mathrm{~m}$ & 61.1 \\
\hline
\end{tabular}

The ${ }^{1} \mathrm{H}-\mathrm{NMR}$ chemical shifts observed for these two benzene systems together with the presence of two oxygenated methyl proton signals at $\delta_{\mathrm{H}} 3.72(6 \mathrm{H}, \mathrm{s})$ suggested the presence of two guaiacyl (3-methoxy-4-hydroxyphenyl) groups in this compound [13]. The ${ }^{13} \mathrm{C}-\mathrm{NMR}$ assignments corroborated the ${ }^{1} \mathrm{H}-\mathrm{NMR}$ assignments for both aromatic rings. In addition, the ${ }^{1} \mathrm{H}-\mathrm{NMR}$ spectrum of $\mathbf{1}$ also established a $\mathrm{C}(7)-\mathrm{O}-\mathrm{C}\left(9^{\prime}\right)$ tetrahydrofuran skeleton [14], similar to that of 4 [12]. The proton signals at $\delta_{\mathrm{H}} 4.76(1 \mathrm{H}, \mathrm{d}, J=6.4 \mathrm{~Hz}, \mathrm{H}-7), 2.31(1 \mathrm{H}, \mathrm{m}, \mathrm{H}-8), 3.88(1 \mathrm{H}, \mathrm{dd}, J=9.5,6.4 \mathrm{~Hz}, \mathrm{H}-9 \mathrm{a}), 3.64$ (1H, m, H-9b); and $2.82\left(1 \mathrm{H}, \mathrm{dd}, J=13.5,4.3 \mathrm{~Hz}, \mathrm{H}-7^{\prime} \mathrm{a}\right), 2.36\left(1 \mathrm{H}, \mathrm{dd}, J=13.0,11.8 \mathrm{~Hz}, \mathrm{H}-7^{\prime} \mathrm{b}\right), 2.62\left(1 \mathrm{H}, \mathrm{m}, \mathrm{H}-8^{\prime}\right)$, $3.82\left(1 \mathrm{H}, \mathrm{dd}, J=7.5 \mathrm{~Hz}, 7.5 \mathrm{~Hz}, \mathrm{H}-9^{\prime} \mathrm{a}\right)$ and $3.54\left(1 \mathrm{H}, \mathrm{dd}, J=7.6 \mathrm{~Hz}, 7.6 \mathrm{~Hz}, \mathrm{H}-9{ }^{\prime} \mathrm{b}\right)$ were assigned to the substructures ${ }^{7} \mathrm{CH}-{ }^{8} \mathrm{CH}-{ }^{9} \mathrm{CH}_{2} \mathrm{O},{ }^{7} \mathrm{CH}_{2-}{ }^{8} \mathrm{CH}_{-}{ }^{\prime} \mathrm{CH}_{2}$, and ${ }^{8} \mathrm{CH}_{-}{ }^{8} \mathrm{CH}$ from its ${ }^{1} \mathrm{H}-{ }^{1} \mathrm{H} \mathrm{COSY}$ (Figure 2).

Figure 2. Key ${ }^{1} \mathrm{H}-{ }^{1} \mathrm{H}$ COSY (bold dash) and HMBC (arrow) correlations of $\mathbf{1}$.

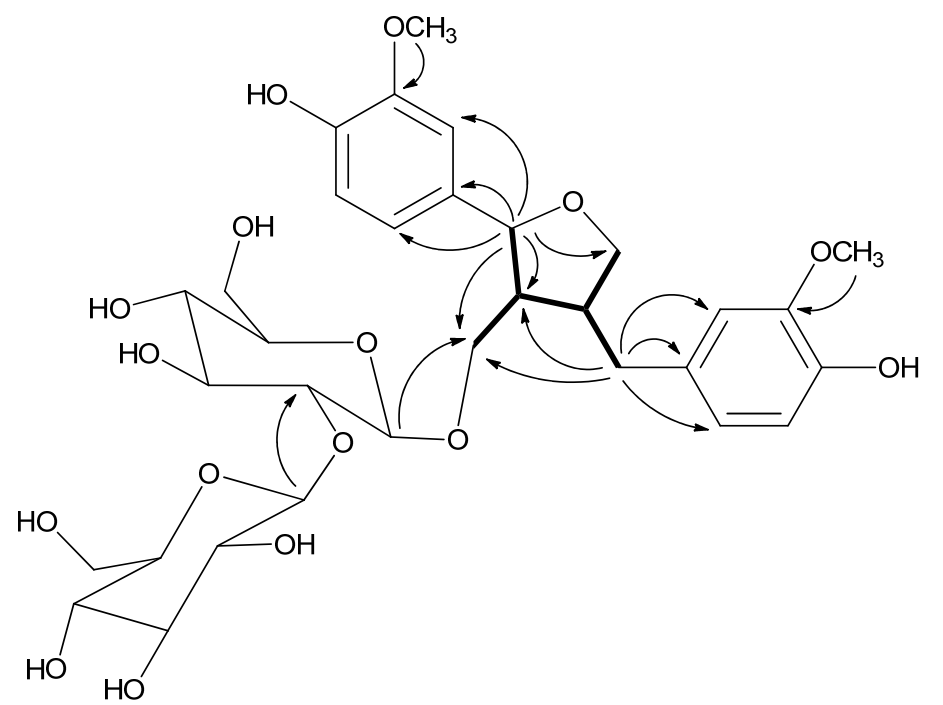


The ${ }^{1} \mathrm{H}-\mathrm{NMR}$ spectrum of $\mathbf{1}$ also gave signals for two glucose moieties (Table 1). In the HSQC spectrum, two anomeric protons at $\delta_{\mathrm{H}} 4.32\left(1 \mathrm{H}, \mathrm{d}, J=7.7 \mathrm{~Hz}, \mathrm{H}-1^{\prime \prime}\right)$ and $4.43\left(1 \mathrm{H}, \mathrm{d}, J=7.8 \mathrm{~Hz}, \mathrm{H}-1^{\prime \prime \prime}\right)$, correlated respectively with signals at $\delta \mathrm{c} 101.4$ and 104.4. Both the anomeric protons appear as doublet signals with coupling constants around $8.0 \mathrm{~Hz}$, consistent with axial orientations for these two monosaccharide moieties.

The ${ }^{13} \mathrm{C}-\mathrm{NMR}$ spectrum of $\mathbf{1}$ analyzed with the aid of DEPT spectrum showed the presence of two methoxy $\left[\delta \mathrm{c} 55.6\left(\mathrm{OMe}-3,3^{\prime}\right)\right]$, three methylene $\left[\delta \mathrm{c} 72.3\left(\mathrm{C}-9^{\prime}\right), 66.7\right.$ (C-9) and $\left.32.4\left(\mathrm{C}-7^{\prime}\right)\right]$, three methine [ $\delta \mathrm{c} 81.7(\mathrm{C}-7), 50.1(\mathrm{C}-8)$ and $42.1\left(\mathrm{C}-8^{\prime}\right)$ ], twelve signals of two glucose moieties, and twelve aromatic carbons, of which six were quaternary $(\delta \mathrm{c} 147.7,147.3,145.5,144.5,134.4$, and 131.8), and the remaining six were unsubstituted aromatic carbons $(\delta \mathrm{c} 120.8,118.7,115.3,115.0,112.9$, and 110.1) (Table 1). All the information mentioned above substantiates the identity of $\mathbf{1}$ as a tetrahydrofuran lignan diglucoside $[15,16]$.

The HMBC correlations between H-7 and C-1, C-2, and C- 6 of the benzene ring indicated the linkage of $\mathrm{C}-7$ and this aromatic ring. Similarly, C-7' was connected to $\mathrm{C}-1^{\prime}$ of another aromatic ring as evidenced by the HMBC correlations between $\mathrm{H}-7^{\prime}$ and $\mathrm{C}-1^{\prime}, \mathrm{C}-2^{\prime}$ and $\mathrm{C}-6^{\prime}$ (Figure 2). The attachment of the inner glucose residue to C-9 was suggested by the HMBC correlation of the anomeric proton at $\delta_{\mathrm{H}}$ $4.32(\mathrm{~d}, J=7.7 \mathrm{~Hz})$ with the signal at $\delta_{\mathrm{H}} 66.7$ (C-9). The $1 \rightarrow 2$ interglycosidic linkage with the second glucose moiety was deduced from the HMBC correlation between $\mathrm{H}-1^{\prime \prime \prime}\left(\delta_{\mathrm{H}} 4.43, \mathrm{~d}, J=7.8 \mathrm{~Hz}\right)$ and $\mathrm{C}-2^{\prime \prime}$ at $\delta \mathrm{c} 81.9$. The assignment of the $1 \rightarrow 2$ interglycosidic linkage of the two glucoses has also been confirmed by comparison with the ${ }^{13} \mathrm{C}$ NMR spectral data of the reference [17].

The relative configuration of $\mathbf{1}$ was determined as described below. The ROESY spectrum displayed correlations between $\mathrm{H}-8\left(\delta_{\mathrm{H}} 2.31\right)$ and $\mathrm{H}-8^{\prime}\left(\delta_{\mathrm{H}} 2.62\right)$ but was not observed between $\mathrm{H}-7\left(\delta_{\mathrm{H}} 4.76\right)$ and $\mathrm{H}-8\left(\delta_{\mathrm{H}} 2.31\right)$, leading to the assignments of cis and trans orientations for $\mathrm{H}-8 / \mathrm{H}-8^{\prime}$ and $\mathrm{H}-7 / \mathrm{H}-8$, respectively (Figure 3 ).

Figure 3. Key ROESY correlations (double-headed arrow) for the aglycone moiety of $\mathbf{1 .}$

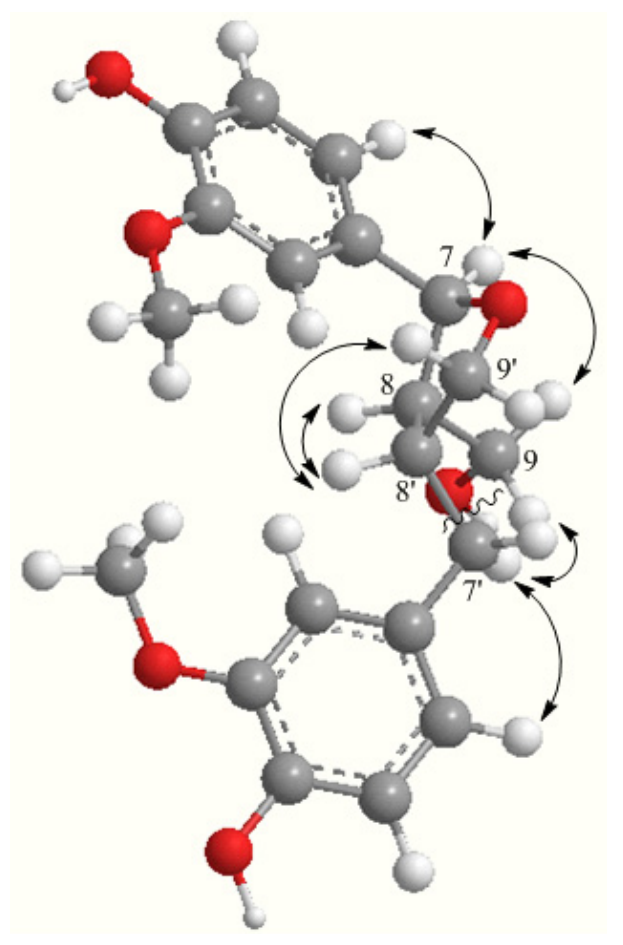


In addition, a large coupling constant $(J=6.4 \mathrm{~Hz})$ of $\mathrm{H}-7 / \mathrm{H}-8$ [18] and the proton signal of $\mathrm{H}-7$ at ca. 4.70 [19] further confirmed a trans configuration between the H-7 and H-8 protons. The absolute configuration of 1 was determined as $7 S, 8 R, 8^{\prime} R$ by comparison of its optical rotation $\left([\alpha]_{\mathrm{D}}^{25}=+15.1^{\circ}\right)$ with literature reports [19-21]. These data agreed well with the circular dichroism spectrum of 1 . The positive Cotton effect $[\Delta \varepsilon:+4.35(215 \mathrm{~nm})]$ of $\mathbf{1}$ was in good agreement with that of $\left(7 S, 8 R, 8^{\prime} R\right)-5,5^{\prime}$-dimethoxylariciresinol 9'-O- $\beta$-D-glucopyranoside $[\Delta \varepsilon:+11.1(211 \mathrm{~nm})][18]$ and the negative Cotton effect $[\Delta \varepsilon:-2.26(291 \mathrm{~nm})]$ of 1 was similar with that of $(+)$-lariciresinol 4'-O- $\beta$-D-glucopyranoside $[\Delta \varepsilon:-0.47(280 \mathrm{~nm})][22]$ and (+)-lariciresinol 9'-stearate $(289 \mathrm{~nm})[23]$. In summary, the structure of 1 was established as $\left(7 S, 8 R, 8^{\prime} R\right)-(+)$ lariciresinol 9-O- $\beta$-D-glucopyranosyl $(1 \rightarrow 2)-\beta$-D-glucopyranoside, and named tianshanoside $A$. This new compound is a lariciresinol 9-O-diglucoside derivative, while its monoglucoside (lariciresinol 9-O-glucoside) had previously been isolated from the root of Isatis indigotica [24]. This is the first report of isolation of a lignan skeleton from the genus Viola.

The known compounds 2-4 were identified as syringin (2) [10], picraquassioside C (3) [11], and aketrilignoside B (4) [12] (Figure 1), respectively, by comparison of their NMR and MS data with those reported. All these compounds were reported for the first time from $V$. tianshanica. Compounds 1, 3, and 4 were tested in vitro for their cytotoxicities against two human tumor cell lines, gastric cancer Ags and liver cancer HepG2 cells, using the CCK-8 assay. None of the tested compounds showed any significant cytotoxic activities at concentrations up to $0.2 \mathrm{mM}$.

\section{Experimental}

\subsection{General Procedures}

NMR spectra were recorded on a Bruker DRX-400 or a DRX-600 spectrometer (Bruker, Fallanden, Switzerland) with TMS as an internal standard. ESI-MS spectra were obtained on an Agilent SL G1946D single quadrupole mass spectrometer (Agilent, Foster, CA, USA). HRESIMS was measured on a Bruker APEX III TESLA FTMS spectrometer (Bruker). Column chromatography was carried out on silica gel (200-300 mesh, Qingdao Marine Chemical Factory, Qingdao, China), Sephadex LH-20 (Pharmacia, Uppsala, Germany) and Chromatorex ODS (30-50 $\mu \mathrm{m}$, Fuji Silysia Chemical Co. Ltd., Aichi, Japan). Semi-preparative HPLC separation was performed on an LC3000 system equipped with a P3000 pump, a UV3000 detector (Beijing Chuangxintongheng Science \& Technology Co. Ltd., Beijing, China), and a Luna RP-18 column (250 mm $\times 10 \mathrm{~mm}, 10 \mu \mathrm{m}$, Phenomenex, Torrance, CA, USA). Optical rotation was determined on a Rudolph Autopol I polarimeter (Rudolph Research Analytical, Hackettstown, NJ, USA). Circular dichrosim spectroscopy was recorded on a Jasco 810 spectropolarimeter (Jasco Corporation, Tokyo, Japan).

\subsection{Plant Material}

The whole plant of $V$. tianshanica was collected from the Xinjiang Uygur Autonomous Region, China, in June 2012, and authenticated by Dr. Zhihong Cheng. A voucher specimen (NO. 201206TSJC) is deposited at the Herbarium of Materia Medica, School of Pharmacy, Fudan University, Shanghai, China. 


\subsection{Extraction and Isolation}

The dried whole plant of $V$. tianshanica $(20 \mathrm{~kg})$ was extracted thrice with $70 \%$ aqueous ethanol $(20 \mathrm{~L})$ at room temperature for $4 \mathrm{~h}$. The ethanolic extracts were combined and evaporated to dryness under reduced pressure, yielding a dark green residue $(1,200 \mathrm{~g})$. The residue was suspended in water $(2 \mathrm{~L})$ and partitioned successively with petroleum ether $\left(60-90^{\circ} \mathrm{C}\right)$, ethyl acetate, and $n$-butanol ( $2 \mathrm{~L}$ each) to yield the three corresponding extracts. The ethyl acetate extract $(280 \mathrm{~g})$ was fractionated on a silica gel column and eluted with increasing polarities of mixture of $\mathrm{CH}_{2} \mathrm{Cl}_{2}$ and $\mathrm{MeOH}$ to afford nine fractions A-I. Fraction E was subjected to repeated column chromatography on silica gel and eluted with a gradient solvent system of $\mathrm{CH}_{2} \mathrm{Cl}_{2}-\mathrm{MeOH}(50: 1,30: 1,20: 1,10: 1,5: 1,2: 1$, and 1:1). The fraction eluting with $\mathrm{CH}_{2} \mathrm{Cl}_{2}-\mathrm{MeOH}(10: 1)$ was re-chromatographed on an ODS column eluted with $\mathrm{H}_{2} \mathrm{O}-\mathrm{MeOH}(6: 4)$, followed by semi-preparative HPLC using $\mathrm{MeOH}-\mathrm{H}_{2} \mathrm{O}(15: 85)$ as eluting solvents to give compound 2 $(6.0 \mathrm{mg})$. Fraction $\mathrm{F}$ was separated by a silica gel column with a gradient solvent system of $\mathrm{CH}_{2} \mathrm{Cl}_{2}-\mathrm{MeOH}(50: 1,30: 1,20: 1,10: 1,5: 1,2: 1$, and 1:1). The 10:1 eluate was then purified by ODS column chromatography with $\mathrm{MeOH}-\mathrm{H}_{2} \mathrm{O}(3: 7)$ and semi-preparative $\mathrm{HPLC}\left(20 \% \mathrm{CH}_{3} \mathrm{CN}\right)$ to give compounds 3 (25 mg) and 4 (50 mg). Fraction G was chromatographed on a Sephadex LH-20 column eluting with $\mathrm{MeOH}$, followed by purification on a semi-preparative $\mathrm{HPLC}$ with $\mathrm{MeOH}-\mathrm{H}_{2} \mathrm{O}(35: 65)$ at a flow rate of $3 \mathrm{~mL} / \mathrm{min}$ to give compound $\mathbf{1}(5.0 \mathrm{mg})$.

\subsection{Spectral Data}

Tianshanoside $A$ (1). White amorphous powder, $[\alpha]_{\mathrm{D}}^{25}=+15.1^{\circ}(c 0.20, \mathrm{MeOH})$; IR $(\mathrm{KBr}) v_{\max } 3,387$ (HO), 2,924, 1,637, 1,513 (benzene rings), 1,452, 1,249, 1,121, 1,060, 764, $617 \mathrm{~cm}^{-1}$; UV (MeOH) $\lambda_{\max }$ 230, $280 \mathrm{~nm}$; Circular dichrosim (MeOH): $215(\Delta \varepsilon+4.35), 291(\Delta \varepsilon-2.26) \mathrm{nm} ;{ }^{1} \mathrm{H}$ - and ${ }^{13} \mathrm{C}-\mathrm{NMR}$ data, see Table 1; ESI-MS $m / z 707[\mathrm{M}+\mathrm{Na}]^{+}$; HRESIMS $m / z 707.2531[\mathrm{M}+\mathrm{Na}]^{+}$(calcd for $\mathrm{C}_{32} \mathrm{H}_{44} \mathrm{O}_{16} \mathrm{Na}$, 707.2521).

Syringin (2). Amorphous powder. ${ }^{1} \mathrm{H}-\mathrm{NMR}\left(\mathrm{CD}_{3} \mathrm{OD}\right): \delta_{\mathrm{H}} 6.77(s, \mathrm{H}-2,6), 6.57(d, 15.8 \mathrm{~Hz}, \mathrm{H}-7), 6.35$ $(d t, 15.8,5.6 \mathrm{~Hz}, \mathrm{H}-8), 4.24(d, 5.6 \mathrm{~Hz}, \mathrm{H}-9,10), 3.88$ ( $s, 3,5-\mathrm{OMe}) .{ }^{13} \mathrm{C}-\mathrm{NMR}\left(\mathrm{CD}_{3} \mathrm{OD}\right): \delta_{\mathrm{C}} 154.3(\mathrm{C}-3$, 5), 135.2 (C-1), 131.2 (C-7), 130.0 (C-8), 105.4 (C-2, 6), 105.3 (C-1'), 78.3 (C-5'), 77.8 (C-3'), 75.7 (C-2'), $71.3\left(\mathrm{C}-4^{\prime}\right), 63.5(\mathrm{C}-9), 62.5\left(\mathrm{C}-6^{\prime}\right)$. ESI-MS: $m / z 395[\mathrm{M}+\mathrm{Na}]^{+}, 411[\mathrm{M}+\mathrm{K}]^{+}$.

Picraquassioside C (3). Amorphous powder. ${ }^{1} \mathrm{H}-\mathrm{NMR}\left(\mathrm{CD}_{3} \mathrm{OD}\right): \delta_{\mathrm{H}} 6.81\left(d, 1.5 \mathrm{~Hz}, \mathrm{H}-2^{\prime}, 6^{\prime}\right), 6.73(d$, $\left.1.5 \mathrm{~Hz}, \mathrm{H}-3^{\prime \prime}, 5^{\prime \prime}\right), 6.55$ ( $\left.b r d, 15.9 \mathrm{~Hz}, \mathrm{H}-1^{\prime \prime \prime}\right), 6.35$ (dt, 15.9, $\left.5.5 \mathrm{~Hz}, \mathrm{H}-2^{\prime \prime \prime}\right), 5.03$ (d, $\left.5.4 \mathrm{~Hz}, \mathrm{H}-1\right), 4.80$ (d, $7.3 \mathrm{~Hz}, \mathrm{H}-1-\mathrm{Glc}), 4.25$ ( $\left.m, \mathrm{H}-2,3^{\prime \prime \prime} \mathrm{a}, 3^{\prime \prime \prime} \mathrm{b}\right), 3.86$ ( $\left.s, 3^{\prime}, 5^{\prime}-\mathrm{OMe}\right), 3.85$ ( $\left.\mathrm{s}, 3^{\prime \prime}, 5^{\prime \prime}-\mathrm{OMe}\right), 3.2-3.6$ ( $m$, H-2-6-Glc, H-3). ${ }^{13} \mathrm{C}-\mathrm{NMR}\left(\mathrm{CD}_{3} \mathrm{OD}\right): \delta_{\mathrm{C}} 154.2\left(\mathrm{C}-2^{\prime \prime}, 6^{\prime \prime}\right), 153.7\left(\mathrm{C}-3^{\prime}, 5^{\prime}\right), 139.2\left(\mathrm{C}-1^{\prime}\right), 136.8\left(\mathrm{C}-1^{\prime \prime}\right)$, 135.4 (C-4'), 134.7 (C-4"), 131.2 (C-2'"'), 129.9 (C-1"'), 105.7 (C-2', 6'), 105.6 (C-1-Glc), 104.7 (C-3", 5"), 87.9 (C-2), 78.3 (C-5-Glc), 78.1 (C-3-Glc), 75.7 (C-2-Glc), 74.0 (C-1), 71.3 (C-4-Glc), 63.5 (C-3"'), 62.5 (C-6-Glc), 61.9 (C-3), 56.9 (C-3', 5'-OMe), 56.6 (C-3", 5"'-OMe). ESI-MS: $m / z 621$ [M + Na], 637 $[\mathrm{M}+\mathrm{K}]^{+}$.

Aketrilignoside B (4). Colorless gum. ${ }^{1} \mathrm{H}-\mathrm{NMR}\left(\mathrm{CD}_{3} \mathrm{OD}\right): \delta_{\mathrm{H}} 7.36\left(s, \mathrm{H}-2^{\prime}, 6^{\prime}\right), 6.78(s, \mathrm{H}-2,6), 4.84(d$, $8.7 \mathrm{~Hz}, \mathrm{H}-7), 4.38$ ( $\left.m, \mathrm{H}-8^{\prime}\right), 4.30$ (d, $\left.7.8 \mathrm{~Hz}, \mathrm{H}-1-\mathrm{Glc}\right), 4.26$ (m, H-9'a), 4.21 (m, H-9'b), 4.09 (dd, 10.3, 
4.1 Hz, H-9a), 3.94 ( $s, 3^{\prime}, 5^{\prime}-\mathrm{OMe}$ ), 3.88 ( $s, 3$, 5-OMe), 3.62 ( $m$, H-9a), 3.20-3.85 (m, H-2-6-Glc), 2.75 ( $m, \mathrm{H}-8) .{ }^{13} \mathrm{C}-\mathrm{NMR}\left(\mathrm{CD}_{3} \mathrm{OD}\right): \delta_{\mathrm{C}} 200.5$ (C-7'), 149.3 (C-3, 5), $149.2\left(\mathrm{C}-3^{\prime}, 5^{\prime}\right), 142.9\left(\mathrm{C}-4^{\prime}\right), 136.3(\mathrm{C}-4)$, 132.6 (C-1), 128.7 (C-1'), 107.8 (C-2', 6'), 105.3 (C-2, 6), 105.1 (C-1-Glc), 85.3 (C-7), 78.2 (C-3-Glc), 78.1 (C-5-Glc), 75.2 (C-2-Glc), 71.7 (C-9'), 71.6 (C-4-Glc), 69.1 (C-9), 62.8 (C-6-Glc), 57.1 (C-3', 5'-OMe), 56.8 (C-3, 5-OMe), 53.3 (C-8), 50.1 (C-8'). ESI-MS: $m / z 597[\mathrm{M}+\mathrm{H}]^{+}, 619[\mathrm{M}+\mathrm{Na}]^{+}$.

\subsection{Cytotoxicity Evaluation}

Two human cancer cell lines, the gastric cancer Ags cells and HepG2 liver cancer cells were obtained from the Cell Bank of the Chinese Academy of Sciences (Shanghai, China). The Ags cell line was cultured in a Ham's/F12 medium (Hyclone, Logan, UT, USA), supplemented with 10\% fetal bovine serum (Gibco). The HepG2 cell line was cultured in DMEM medium (Hyclone), supplemented with $10 \%$ fetal bovine serum (Gibco). Cells were maintained at $37{ }^{\circ} \mathrm{C}$ in a $95 \%$ air- $5 \% \mathrm{CO}_{2}$ atmosphere. The cytotoxicity of the compounds was determined in vitro using the Cell Counting Kit-8 (CCK-8) assay kit (Dojindo Laboratories, Tokyo, Japan), according to the manufacturer's instructions. The sample compounds were dissolved in DMSO, and then further diluted. Cells were plated at a density of $1.0 \times 10^{5}$ per well in a 96-well microplate and incubated at $37{ }^{\circ} \mathrm{C}$ for $24 \mathrm{~h}$. The cells were treated with various concentrations of test compounds (the final concentrations of the compounds were $0,25,75,100,150$, $200 \mu \mathrm{M} / \mathrm{mL}$ ) in quadruplicate for $72 \mathrm{~h}$. Then, $20 \mu \mathrm{L}$ of the solution of CCK-8 was added into each well, and the plates were further incubated for an additional $1 \mathrm{~h}$. The absorbance was measured at $450 \mathrm{~nm}$ with a Varioskan Flash microplate reader (Thermo Scientific, Waltham, MA, USA).

\section{Conclusions}

Three lignan glycosides including a new one, tianshanoside A, and a phenylpropanoid glycoside were isolated for the first time from the dried whole plant of $V$. tianshanica. This is the first report of lignans from Viola species. Three lignan glycosides exhibited no significant inhibitory activities against two human tumor cell lines, gastric cancer Ags or liver cancer HepG2.

\section{Acknowledgments}

We would like to thank Jeffrey C. Moore for revision of the English and two anonymous reviewers for valuable comments on the manuscript. This work was supported by the National Natural Science Foundation of China (81073025), the Scientific Research Foundation for the Returned Overseas Chinese Scholars, Ministry of Education of China, and a grant from the Key Laboratory of Modern Chinese Preparation, Ministry of Education of China.

\section{Conflicts of Interest}

The authors declare no conflict of interest.

\section{References}

1. Editorial Committee of Chinese Materia Medica. Chinese Material Medica Uygur Medicine Volume; Shanghai Science and Technology Press: Shanghai, China, 2005; pp. 88-89. 
2. Shen, X.Y.; Xie, C.X.; Deng, W.P. Analysis of volatile oil from Viola tianshanica Maxim by GC/MS. J. Chin. Mass Spec. Soc. 2009, 30, 51-54.

3. Yang, J.; Yang, H.; Chen, L.Q.; Shen, Z.L. A study on extraction technology and anti-inflammatory effect of essential oil of Viola tianshanica. J. Hubei Univ. Nat. 2011, 28, 5-7.

4. Ma, X.M; Zhou, X.Y.; Zhang, L.; Wang, Y.N.; Ding, J.B.; Tian, S.G. Antimicrobial test in vitro of extracts from Viola tianshanica Maxim. Lishizhen Med. Mater. Med. Res. 2004, 15, 470-471.

5. Shen, X.Y.; Xie, C.X. Study on antioxidantive activity of extracts from Viola tianshanica Maxim. Food Sci. 2009, 30, 139-141.

6. Yu, J.D.; Dai, Z.; Lin, R.C. Chemical constituents of Viola tianshanica. China J. Chin. Mat. Med. 2009, 34, 2916-2917.

7. Xiang, B.; Du, G.H.; Wang, X.C.; Zhang, S.X.; Qin, X.Y.; Kong, J.Q.; Cheng, K.D.; Li, Y.J.; Wang, W. Elucidating the structure of two cyclotides of Viola tianshanica Maxim by MALDI TOF/TOF MS analysis. Acta Pharm. Sin. 2010, 45, 1402-1409.

8. Li, W.; Xie, J.Y.; Li, H.; Zhang, Y.Y.; Cao, J.; Cheng, Z.H.; Chen, D.F. Viola yedoensis liposoluble fraction ameliorates lipopolysaccharide-induced acute lung injury in mice. Am. J. Chin. Med. 2012, 40, 1007-1018.

9. Cao, J.; Qin, Y.; Yin, C.L.; Cheng, Z.H. Chemical constituents of Viola yedoensis and their antioxidant activity. Chin. J. Exp. Trad. Med. Form. 2013, 19, 282-286.

10. Yuan, Z.; Zhou, B.Y.; Zhang, Z.C.; Men, T.C.L.; Li, X. Glycosides from Glehnia littoralis. J. Shenyang Pharm. Univ. 2002, 3, 157-160.

11. Yoshikawa, K.; Sugawara, S.; Arihara, S. Phenylpropanoids and other secondary metabolites from fresh fruits of Picrasma quassioides. Phytochemistry 1995, 40, 253-256.

12. Guan, S.H.; Xia, J.M.; Lu, Z.Q.; Chen, G.T.; Jiang, B.H.; Liu, X.; Guo, D.A. Structure elucidation and NMR spectral assignments of three new lignan glycosides from Akebia trifoliatia. Magn. Reson. Chem. 2008, 46, 186-190.

13. Erdemoglu, N.; Sahin, E.; Sener, B.; Ide, S. Structural and spectroscopic characteristics of two lignans from Taxus baccata L. J. Mol. Struct. 2004, 692, 57-62.

14. Zhao, Y.; Wang, Y.; Chen, Y.G.; Wang, J.H.; Zhao, Y.; Luo, L. Structural studies on a lignan glucoside from Euphorbia hirta. J. Yunnan Norm. Univ. 2011, 31, 7-10.

15. Achenbach, H.; Benirschke, M.; Torrenegra, R. Alkaloids and other compounds from seeds of Tabernaemontana cymosa. Phytochemistry 1997, 45, 325-335.

16. Subbaraju, G.V.; Kumar, K.K.K.; Raju, B.L.; Pillai, K.R. Justiciresinol, a new furanoid lignan from Justicia glauca. J. Nat. Prod. 1991, 54, 1639-1641.

17. Grougnet, R.; Magiatis, P.; Mitaku, S.; Terzis, A.; Tillequin, F.; Skaltsounis, A.L. New lignans from the perisperm of Sesamum indicum. J. Agric. Food Chem. 2006, 54, 7570-7574.

18. Nguyen, X.N.; Lee, H.Y.; Kim, N.Y.; Park, S.J.; Kim, E.S.; Han, J.E.; Yang, H.J.; Kim, S.Y. Stereochemical assignment of five new lignan glycosides from Viscum album by NMR study combined with CD spectroscopy. Magn. Reson. Chem. 2012, 50, 772-777.

19. Jung, K.Y.; Kim, D.S.; Oh, S.Y.; Park, S.H.; Lee, I.S.; Lee, J.J.; Shin, D.H.; Lee, H.K. Magnones A and B, novel anti-PAF tetrahydrofuran lignans from the flower buds of Magnolia fargesii. J. Nat. Prod. 1998, 61, 808-811. 
20. Yuasa, K.; Ide, T.; Otsuka, H.; Ogimi, C.; Hirata, E.; Takushi, A.; Takeda, Y. Lignan and neolignan glycosides from stems of Alangium premnifolium. Phytochemistry 1997, 45, 611-615.

21. Nishiwaki, H.; Kumamoto, M.; Shuto Y.; Yamauchi, S. Stereoselective syntheses of all stereoisomers of lariciresinol and their plant growth inhibitory activities. J. Agric. Food Chem. 2011, 59, 13089-13095.

22. Machida, K.; Unagami, E.; Ojima, H.; Kikuchi, M. Studies on the constituents of Syringa species. XII. New glycosides from the leaves of Syringa reticulata (Blume) HARA. Chem. Pharm. Bull. 2003, 51, 883-884.

23. Wei, H.H.; Xu, H.H.; Xie, H.H.; Xu, L.X.; Wei, X.Y. Sesquiterpenes and lignans from Tephrosia vogelii. Helv. Chim. Acta 2009, 92, 370-374.

24. Zuo, L.; Li, J.B.; Xu, J.; Yang, J.Z.; Zhang, D.M.; Tong, Y.L. Studies on chemical constituents in root of Isatis indigotica. China J. Chin. Mat. Med. 2007, 32, 688-691.

Sample Availability: Samples of the compounds 1-4 are available from the authors.

(C) 2013 by the authors; licensee MDPI, Basel, Switzerland. This article is an open access article distributed under the terms and conditions of the Creative Commons Attribution license (http://creativecommons.org/licenses/by/3.0/). 